\title{
Impact of Arsenic Toxicity on Black Gram and Its Amelioration Using Phosphate
}

\author{
Saumya Srivastava and Yogesh Kumar Sharma \\ Department of Botany, University of Lucknow, Lucknow, Uttar Pradesh 226007, India \\ Correspondence should be addressed to Saumya Srivastava; sonata906@gmail.com
}

Received 27 May 2013; Accepted 2 July 2013

Academic Editors: A. S. Faqi, A. I. Haza, and B. Zhou

Copyright ( 12013 S. Srivastava and Y. K. Sharma. This is an open access article distributed under the Creative Commons Attribution License, which permits unrestricted use, distribution, and reproduction in any medium, provided the original work is properly cited.

\begin{abstract}
The toxicity of arsenic in soil and ground water is one of the most important environmental problems particularly in South-East Asia. Arsenic-polluted irrigation water creates hazard in soil environment and also in crop quality. In the present study, response of black gram (Vigna mungo L.) to arsenic with or without phosphate application was investigated. Arsenic-treated plants showed reduction in their growth and pigment content. Arsenic significantly enhanced lipid peroxidation, electrolyte leakage, and level of proline showing oxidative stress. Arsenic toxicity was associated with an increase in the activities of antioxidative enzymes like superoxide dismutase, peroxidase, and ascorbate peroxidase whereas catalase activity decreased at higher arsenic dose. Joint application of phosphate with arsenic resulted in significant alterations in most of the parameters tested under the purview of arsenic treatment alone which lead to better growth in black gram.
\end{abstract}

\section{Introduction}

Arsenic (As) is a toxic metalloid [1], universally present in many environments. It is highly toxic to all forms of life. Arsenic is a group I carcinogen [2] and occurs predominantly in inorganic form as arsenate (AsV) and arsenite (AsIII). Arsenic originates from anthropogenic and geochemical sources [3]. In addition, human activities have caused an accumulation of arsenic in soils through production/use of arsenic-based pesticides [4], manufacture of arsenic based compounds, smelting of arsenic ores, mining processes, and fuel utilization [5]. Thus, human activity has exacerbated the problem of arsenic toxicity. Water supplies, soils, and sediments polluted with arsenic are the major sources of drinking water and food chain contamination in numerous countries $[6,7]$. This has caused a worldwide epidemic of arsenic poisoning, with many people having developed skin lesions, cancers, and other symptoms $[8,9]$. Accumulation of arsenic in human hair $(180-20340 \mu \mathrm{g} / \mathrm{kg})$ and nails $(380-44890 \mu \mathrm{g} / \mathrm{kg}$; [10]) in West Bengal and Bangladesh is indicative of chronic arsenic toxicity. Study shows that, besides groundwater, food is also an important pathway of arsenic in to human system $[11,12]$.
Water is a very important input for crop production and if arsenic contaminated water is used for irrigation, it may create hazard both in soil environment and in crop quality. Twenty percent loss of crop (cereal) production due to high concentration (20 ppm) of arsenic in plant body was reported by Davis et al. [13]. Long-term use of arsenic laden water for irrigation result in higher arsenic levels in agricultural soils [14-16]. In this way, arsenic gets into the grains of plants, such as rice and wheat, and into vegetables and fruit plants when they are grown on arsenic contaminated soils $[11,17,18]$. The presence of arsenic in irrigation water or in soil at high levels could obstruct normal growth of plants with toxicity symptoms like biomass reduction [19], yield losses [20], inhibition of seed germination, decrease in plant height, lower fruit and grain yield [21-23], reduction in root and shoot growth [24], wilting and necrosis of leaf blades [22], and reduction in leaf area and photosynthesis [25].

As arsenic is highly toxic metalloid and its contamination poses a serious threat to plants and animals including humans, efforts are underway worldwide to remediate arsenic contaminated soil and water. People are also working to manage arsenic toxicity in plants through various fertilization 
and nutrient strategies. Arsenic is analogous to phosphate (in the periodic table, both are placed in the same group, Va); both have similar electron configuration and chemical properties and compete for the same uptake carriers in the root plasmalemma [26, 27]. This suggests a possible amelioration method for arsenic toxicity.

In the present study, arsenic-induced toxicity in black gram was studied. We selected black gram as there appears to be very little information about its sensitivity vis-a-vis tolerance to arsenic. It is an important pulse crop in India. Black gram is a rich source of protein. It is also grown for forage and hay [28]. Its crop residues are an important feed for livestock. We studied how arsenic, at 3 concentrations: $0 \mu \mathrm{M}$ (control), $100 \mu \mathrm{M}$, and $200 \mu \mathrm{M}$, affected the growth, levels of oxidative stress markers (proline, malondialdehyde), and antioxidative enzymatic machinery in black gram grown in uncontaminated soil in pots and irrigated with solutions containing arsenic of above concentrations and in the presence or absence of Pi fertilization/application.

\section{Materials and Methods}

2.1. Plant Material and Arsenic Treatments. Black gram (Vigna mungo L. Hepper var. T9) seeds obtained from the authorized agency were surface sterilized with mercuric chloride $(0.1 \%, \mathrm{w} / \mathrm{v})$ and washed thoroughly and presoaked in petri dish for 4 hours containing sodium arsenate $\left(\mathrm{Na}_{2} \mathrm{HAsO}_{4} \cdot 7 \mathrm{H}_{2} \mathrm{O}\right)$ solution of the following concentrations $0 \mu \mathrm{M}$ (control), $100 \mu \mathrm{M}$, and $200 \mu \mathrm{M}$ with or without $40 \mathrm{ppm}$ $\mathrm{K}_{2} \mathrm{HPO}_{4}$ solution. Seeds were then sowed in earthen pots having alluvial soil and compost (in the ratio $3: 1$ ). $500 \mathrm{~mL}$ of arsenic solution of above concentration was given weekly in each pot kept in wire house. Plants were analyzed for all parameters after 30 days of sowing except germination percentage which was evaluated after 5 days of sowing:

Germination \%

$$
=\frac{\text { Number of germinated seeds in a pot }}{\text { Total number of seeds sown in a pot }} \times 100 \text {. }
$$

2.2. Morphological Studies. The root and shoot lengths together with their fresh weights of arsenic treated and untreated (control) black gram plants were measured after washing and rinsing plants with tap and deionised distilled water, respectively. Dry weight of roots and shoots was determined after oven drying at $70^{\circ} \mathrm{C}$ for 48 hours.

2.3. Chlorophyll and Carotenoid Contents. Total chlorophyll, chlorophyll a, and chlorophyll b contents were measured according to Arnon [29]. $100 \mathrm{mg}$ leaves were crushed in $10 \mathrm{~mL}$ $80 \%$ chilled acetone. Extract was centrifuged at $2000 \times \mathrm{g}$ for 10 minutes. Absorbance of supernatant was estimated spectrophotometrically at $645 \mathrm{~nm}$ and $663 \mathrm{~nm}$ using spectrophotometer (Toshniwal TSUV 75). Chlorophyll contents were expressed in terms of $\mathrm{mg}$ chlorophyll present/g fresh weight of tissue. Carotenoid contents were estimated according to method of Duxbury and Yentsch [30].
2.4. Malondialdehyde Contents (Lipid Peroxidation). Lipid peroxidation in terms of malondialdehyde (MDA) was determined to access the membrane damage in black gram plants. For the measurement of lipid peroxidation, TBA (thiobarbituric acid) test was used to measure MDA level as an end product of lipid peroxidation [31].

2.5. Proline Contents. Proline contents estimated according to Bates et al. [32]. One g tissue of black gram plants was extracted with $5 \mathrm{~mL}$ of $0.1 \mathrm{M}$ sulphosalicylic acid and centrifuged at $5000 \times \mathrm{g}$ for 30 minutes. Two $\mathrm{mL}$ of supernatant, $5 \mathrm{~mL}$ glacial acetic acid, and $5 \mathrm{~mL}$ of $140 \mathrm{mM}$ acid ninhydrin were added and shaken vigorously. The mixture was heated in a boiling water bath, and after cooling, the mixture was extracted in $10 \mathrm{~mL}$ of toluene in a separating funnel, and aqueous layer was discarded. The absorbance of the mixture was measured at $520 \mathrm{~nm}$. The proline content was calculated from standard curve and expressed as $\mu \mathrm{M}$ proline/100 mg fresh weight.

2.6. Electrolyte Leakage Percentage (ELP). ELP was calculated according to Sullivan and Ross [33]. Twenty leaf discs were incubated in distilled water at $25^{\circ} \mathrm{C}$ for 2 hour in test tubes, and initial conductivity $(E 1)$ of the bathing medium was measured. The tubes containing the discs were heated at $45^{\circ} \mathrm{C}$ to $55^{\circ} \mathrm{C}$ for 30 minutes to release electrolytes, cooled to $25^{\circ} \mathrm{C}$, and conductivity was measured (E2). Later, the contents were boiled to $100^{\circ} \mathrm{C}$ for 10 minutes, and conductivity was measured after cooling to room temperature (E3). ELP was calculated as follows:

$$
\mathrm{ELP}=\frac{(E 2-E 1)}{E 3} \times 100 .
$$

2.7. Antioxidative Enzymes. Activity of catalase (CAT) enzyme was estimated according to Euler et al. [34]. Peroxidase (POX) activity was estimated according to Luck [35]. Superoxide dismutase (SOD) activity was assayed by the method of Beauchamp and Fridovich [36] by measuring its ability to inhibit the photochemical reduction of nitro blue tetrazoliun (NBT). Ascorbate peroxidase (APX) activity was determined by measuring the decrease in absorbance at $290 \mathrm{~nm}\left(\varepsilon=2.8 \mathrm{mM}^{-1} \mathrm{~cm}^{-1}\right)$ due to oxidation of ascorbic acid to dehydroascorbate [37].

2.8. Protein. Protein contents were determined according to Lowry et al. [38] using bovine serum albumin as a calibration standard.

2.9. Statistical Analysis. The experiment was conducted in a completely randomized design (CRD) with 3 replications. The data were analyzed by One-way ANOVA using software program Sigmastats 3.5. It was followed by comparison of mean values using Holm Sidak method at $P \leq 0.05$.

\section{Results}

3.1. Plant Growth, Biomass, Germination Percentage, and Soluble Protein Content. Arsenic exposure significantly affected 
TABLE 1: Effect of arsenate applied either singly or in combination with phosphate on the height, biomass, germination \% and protein content of black gram.

\begin{tabular}{|c|c|c|c|c|c|}
\hline & Control & $100 \mu \mathrm{M}$ As & $200 \mu \mathrm{M}$ As & $100 \mu \mathrm{M}$ As $+\mathrm{P}$ & $200 \mu \mathrm{M}$ As $+\mathrm{P}$ \\
\hline Germination \% & $96.67 \pm 3.330$ & $83.33 \pm 3.330$ & $70.00 \pm 10.000$ & $86.66 \pm 3.330$ & $76.66 \pm 6.670$ \\
\hline Shoot length $(\mathrm{cm})$ & $20.75 \pm 1.876$ & $13.65 \pm 0.260^{*}$ & $8.25 \pm 0.029^{*}$ & $14.35 \pm 0.087^{*}$ & $13.20 \pm 0.635^{*}$ \\
\hline Root length $(\mathrm{cm})$ & $6.45 \pm 0.318$ & $6.10 \pm 0.577$ & $5.60 \pm 0.346$ & $6.35 \pm 0.491$ & $5.35 \pm 0.087$ \\
\hline Shoot fresh weight (g) & $2.22 \pm 0.176$ & $1.25 \pm 0.020^{*}$ & $0.94 \pm 0.098^{*}$ & $1.34 \pm 0.061^{*}$ & $1.35 \pm 0.176^{*}$ \\
\hline Shoot dry weight (g) & $0.35 \pm 0.032$ & $0.17 \pm 0.003^{*}$ & $0.15 \pm 0.000^{*}$ & $0.22 \pm 0.003^{*}$ & $0.19 \pm 0.017^{*}$ \\
\hline Root fresh weight (g) & $0.18 \pm 0.009$ & $0.14 \pm 0.006$ & $0.12 \pm 0.009^{*}$ & $0.14 \pm 0.009^{*}$ & $0.10 \pm 0.023^{*}$ \\
\hline Root dry weight (g) & $0.027 \pm 0.001$ & $0.016 \pm 0.000$ & $0.014 \pm 0.002$ & $0.016 \pm 0.001$ & $0.013 \pm 0.001$ \\
\hline Protein (mg/100 mg tissue) & $8.49 \pm 0.141$ & $7.01 \pm 0.352^{*}$ & $6.00 \pm 0.147^{*}$ & $7.00 \pm 0.173^{*}$ & $6.90 \pm 0.058^{*}$ \\
\hline
\end{tabular}

$\mathrm{P}=40 \mathrm{ppm} \mathrm{K}_{2} \mathrm{HPO}_{4}$; values are means of three replicates $\pm \mathrm{SE}$ * Data significant at $P<0.05$. Multiple comparisons versus control group (Holm Sidak method) overall significance level $=0.05$.

TABLE 2: Effect of arsenate applied either singly or in combination with phosphate on the pigment levels in black gram.

\begin{tabular}{lcccc}
\hline Treatments & $\begin{array}{c}\text { Total chlorophyl } \\
\text { (mg/g fw of tissue) }\end{array}$ & $\begin{array}{c}\text { Chlorophyll a } \\
\text { (mg/g fw of tissue) }\end{array}$ & $\begin{array}{c}\text { Chlorophyll b } \\
\text { (mg/g fw of tissue) }\end{array}$ & $\begin{array}{c}\text { Carotenoids (mg/g } \\
\text { fw of tissue) }\end{array}$ \\
\hline Control & $2.40 \pm 0.006$ & $1.51 \pm 0.003$ & $0.88 \pm 0.009$ & $0.82 \pm 0.002$ \\
$100 \mu \mathrm{M}$ As & $2.07 \pm 0.007^{*}$ & $1.37 \pm 0.001^{*}$ & $0.70 \pm 0.006^{*}$ & $0.65 \pm 0.002^{*}$ \\
$200 \mu \mathrm{M}$ As & $1.67 \pm 0.004^{*}$ & $1.10 \pm 0.002^{*}$ & $0.58 \pm 0.002^{*}$ & $0.59 \pm 0.002^{*}$ \\
$100 \mu \mathrm{M}$ As + P & $2.13 \pm 0.010^{*}$ & $1.38 \pm 0.005^{*}$ & $0.75 \pm 0.005^{*}$ & $0.68 \pm 0.006^{*}$ \\
$200 \mu \mathrm{M}$ As + P & $1.97 \pm 0.005^{*}$ & $1.30 \pm 0.008^{*}$ & $0.69 \pm 0.004^{*}$ & $0.64 \pm 0.005^{*}$ \\
\hline
\end{tabular}

$\mathrm{P}=40 \mathrm{ppm} \mathrm{K}_{2} \mathrm{HPO}_{4}$; values are means of three replicates $\pm \mathrm{SE}{ }^{*}$ Data significant at $P<0.05$. Multiple comparisons versus control group (Holm Sidak method) overall significance level $=0.05$.

the normal growth and development of black gram plants. The root and shoot length of plants was decreased in higher arsenic doses (Figure 2). When black gram plants treated with arsenic along with phosphate were analyzed, we found that plant height and biomass increased as compared to only arsenic treatments (Table 1; Figures 2 and 3). Germination percentage decreased on increasing the applied arsenic concentrations. From $96.67 \%$, in control, it declined to $70 \%$ in highest arsenic dose. However, on phosphate application, it increased to a substantial level (Figure 1). Soluble protein content also showed a decrease on arsenic application (Table 1; Figure 4).

3.2. Photosynthetic Pigment Levels. Total chlorophyll, chlorophyll $\mathrm{a}, \mathrm{b}$, and carotenoids all were decreased with increasing concentrations of arsenic accompanied by pale green coloration of leaves. In case of joint application of phosphate with arsenic, pigment contents were increased to a great amount (Table 2; Figure 5).

3.3. Oxidative Stress Markers. Arsenic caused electrolyte leakage from leaves, and ELP was highest in $200 \mu \mathrm{M}$ arsenic treatment. However, joint application of phosphate did provide a marginal relief in the form of lowered ELP (Figure 7). Enhanced rate of lipid peroxidation was recorded as indicated by gradually increasing malondialdehyde (MDA) contents in plants exposed to arsenic. MDA contents increased to $52 \%$ in $200 \mu \mathrm{M}$ arsenic treatment (Figure 6). When phosphate was applied jointly with arsenic, elevated levels of MDA suffered considerable reduction. Proline content showed an increase

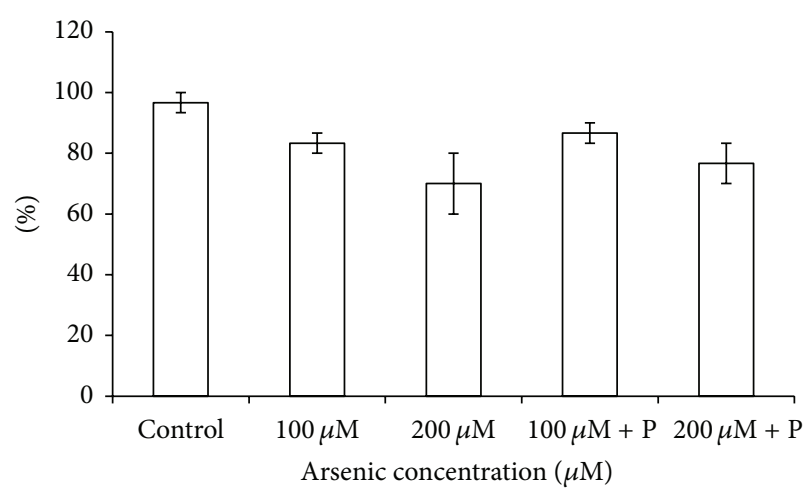

FIGURE 1: Effect of arsenate applied either singly or in combination with phosphate on the germination percentage of black gram. Error bars are the $\pm \mathrm{SE}$ of three replicates; $\mathrm{P}=40 \mathrm{ppm} \mathrm{K} \mathrm{HPO}_{4}$.

on application of arsenic whereas application of phosphate together with arsenic significantly reduced proline content (Table 3; Figure 8).

3.4. Antioxidative Enzymes. The catalase activity was decreased in response to arsenic treatment of $200 \mu \mathrm{M}$. On the contrary, a relief in the rate of reduction of CAT activity was observed in case of joint application of phosphate with arsenic (Table 3; Figure 9). CAT is an $\mathrm{H}_{2} \mathrm{O}_{2}$ splitting enzyme, and due to its low activity, level of $\mathrm{H}_{2} \mathrm{O}_{2}$ probably increased in plants which resulted in reduction in their growth. However, levels of other antioxidative enzymes like APX, POX, and 
TABLE 3: Effect of arsenate applied either singly or in combination with phosphate on the oxidative stress elements and anti oxidative enzymes in black gram.

\begin{tabular}{|c|c|c|c|c|c|}
\hline & Control & $100 \mu \mathrm{M}$ As & $200 \mu \mathrm{M} \mathrm{As}$ & $100 \mu \mathrm{M}$ As $+\mathrm{P}$ & $200 \mu \mathrm{M} \mathrm{As}+\mathrm{P}$ \\
\hline $\begin{array}{l}\text { Lipid peroxidation } \\
(\mathrm{m} \text { mol MDA/100 } \mathrm{mg} \mathrm{fw})\end{array}$ & $135.00 \pm 13.330$ & $139.19 \pm 7.870$ & $255.60 \pm 24.160^{*}$ & $110.36 \pm 2.860$ & $122.76 \pm 1.430$ \\
\hline $\begin{array}{l}\text { ELP } \\
(\%)\end{array}$ & $45.15 \pm 1.640$ & $48.44 \pm 0.900$ & $54.83 \pm 1.860^{*}$ & $41.75 \pm 1.760$ & $43.65 \pm 0.200$ \\
\hline $\begin{array}{l}\text { Proline } \\
(\mu \mathrm{M} / 100 \mathrm{mg} \mathrm{fw})\end{array}$ & $28.50 \pm 6.060$ & $34.75 \pm 5.630$ & $56.00 \pm 4.910$ & $31.75 \pm 7.360$ & $35.75 \pm 7.940$ \\
\hline $\begin{array}{l}\text { Catalase ( } \mu \mathrm{M} \\
\mathrm{H}_{2} \mathrm{O}_{2} \text { degraded/mg protein) }\end{array}$ & $94.31 \pm 6.230$ & $100.24 \pm 2.560$ & $71.95 \pm 4.650^{*}$ & $105.22 \pm 3.020$ & $91.97 \pm 2.160$ \\
\hline $\begin{array}{l}\text { Peroxidase } \\
(\Delta \text { O.D./mg protein })\end{array}$ & $0.02 \pm 0.001$ & $0.11 \pm 0.005^{*}$ & $0.21 \pm 0.019^{*}$ & $0.04 \pm 0.006$ & $0.04 \pm 0.003$ \\
\hline $\begin{array}{l}\text { SOD } \\
\text { (EU/mg protein) }\end{array}$ & $1.07 \pm 0.257$ & $2.07 \pm 0.023^{*}$ & $2.09 \pm 0.279^{*}$ & $1.72 \pm 0.103^{*}$ & $1.95 \pm 0.180^{*}$ \\
\hline $\begin{array}{l}\text { APX (nM ascorbate oxidized } \\
\mathrm{min}^{-1} \mathrm{mg}^{-1} \text { protein). }\end{array}$ & $3.60 \pm 0.011$ & $4.10 \pm 0.006^{*}$ & $4.30 \pm 0.011^{*}$ & $3.90 \pm 0.017^{*}$ & $4.00 \pm 0.017^{*}$ \\
\hline
\end{tabular}

$\mathrm{P}=40 \mathrm{ppm} \mathrm{K}_{2} \mathrm{HPO}_{4}$; values are means of three replicates $\pm \mathrm{SE}{ }^{*}$ Data significant at $P<0.05$. Multiple comparisons versus control group (Holm Sidak method) overall significance level $=0.05$.

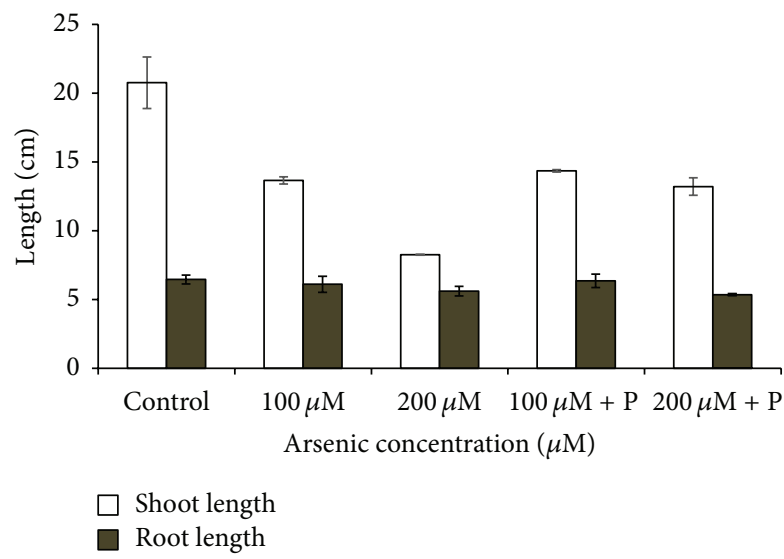

FIGURE 2: Effect of arsenate applied either singly or in combination with phosphate on the shoot and root length of black gram. Error bars are the $\pm \mathrm{SE}$ of three replicates; $\mathrm{P}=40 \mathrm{ppm} \mathrm{K}_{2} \mathrm{HPO}_{4}$.

SOD increased on arsenic exposure (Table 3; Figures 10, 11, and 12).

\section{Discussion}

The arsenic treatment resulted in symptoms of phytotoxicity and in considerable inhibition of initial growth of young black gram plants. There was chlorosis as well as necrosis of leaf tips. It was followed by senescence of leaves. Also, growth of plants was greatly hampered. It was observed that plant biomass together with height decreased markedly with increasing arsenic in treatment solution. The inhibitory effect of arsenic on root growth is in accordance with earlier reports in other plant species [39-41]. For plants grown without $\mathrm{P}$ addition $(\mathrm{P}-)$, there was a significant decrease in biomass production. However, it was less severe in case of As $+\mathrm{P}$ treatments. These

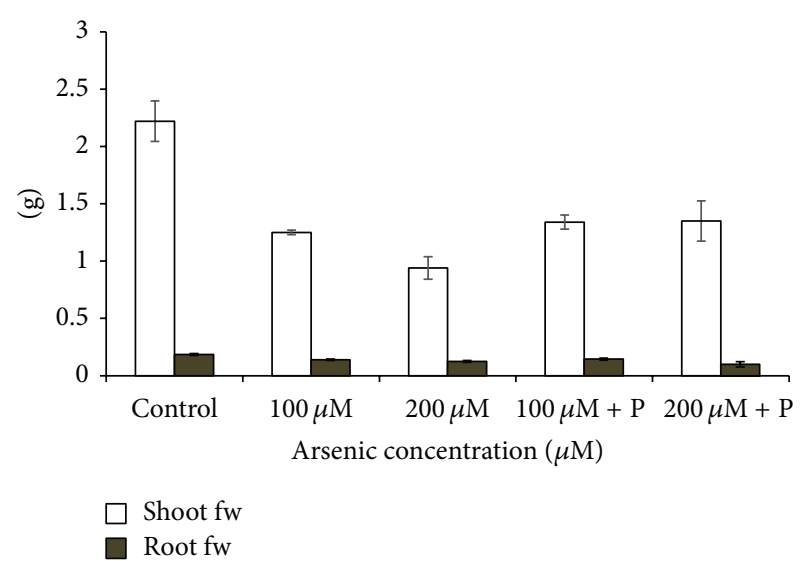

FIGURE 3: Effect of arsenate applied either singly or in combination with phosphate on the shoot and root fresh weight of black gram. Error bars are the \pm SE of three replicates $(\mathrm{fw}=$ fresh weight $)$; $\mathrm{P}=$ 40 ppm K ${ }_{2} \mathrm{HPO}_{4}$.

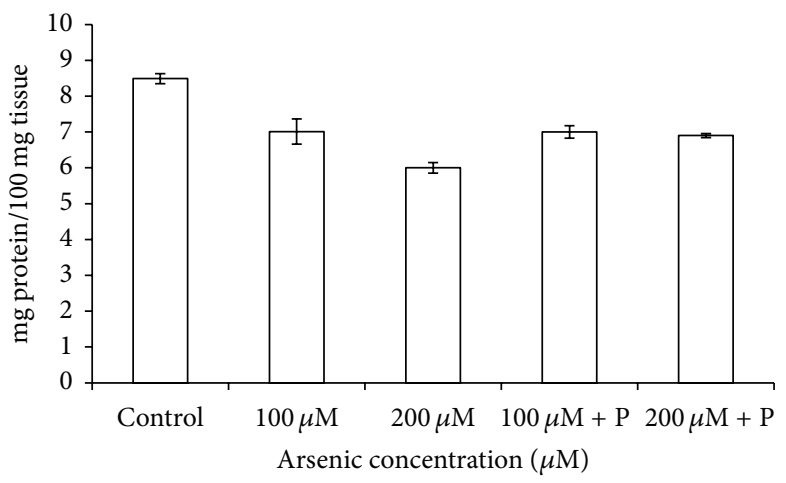

FIGURE 4: Effect of arsenate applied either singly or in combination with phosphate on the protein content of black gram. Error bars are the \pm SE of three replicates; $\mathrm{P}=40 \mathrm{ppm} \mathrm{K}_{2} \mathrm{HPO}_{4}$. 


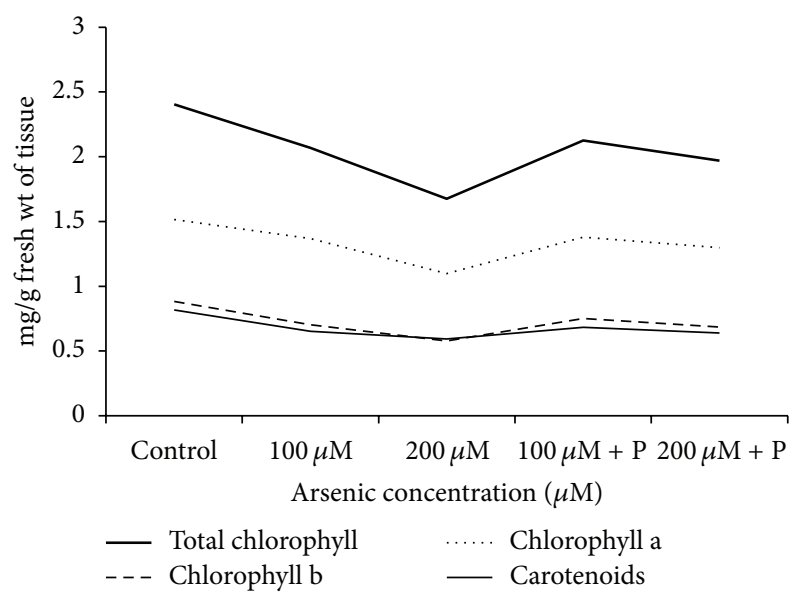

FIGURE 5: Effect of arsenate applied either singly or in combination with phosphate on the pigment contents. $\mathrm{P}=40 \mathrm{ppm} \mathrm{K}_{2} \mathrm{HPO}_{4}$.

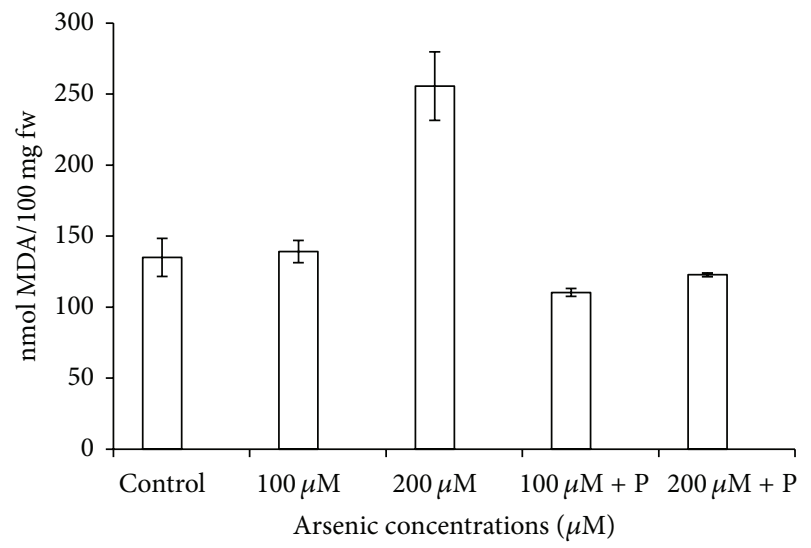

FIGURE 6: Effect of arsenate applied either singly or in combination with phosphate on the lipid peroxidation in black gram. Error bars are the $\pm \mathrm{SE}$ of three replicates $(\mathrm{MDA}=$ malondialdehyde; $\mathrm{fw}=$ fresh weight); $\mathrm{P}=40$ ppm $\mathrm{K}_{2} \mathrm{HPO}_{4}$.

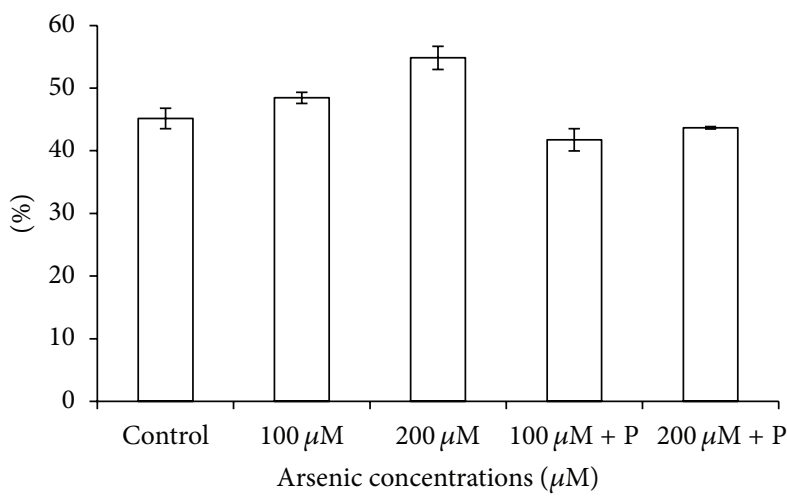

FIGURE 7: Effect of arsenate applied either singly or in combination with phosphate on electrolyte leakage percentage in black gram. Error bars are the $\pm \mathrm{SE}$ of three replicates; $\mathrm{P}=40 \mathrm{ppm} \mathrm{K}_{2} \mathrm{HPO}_{4}$.

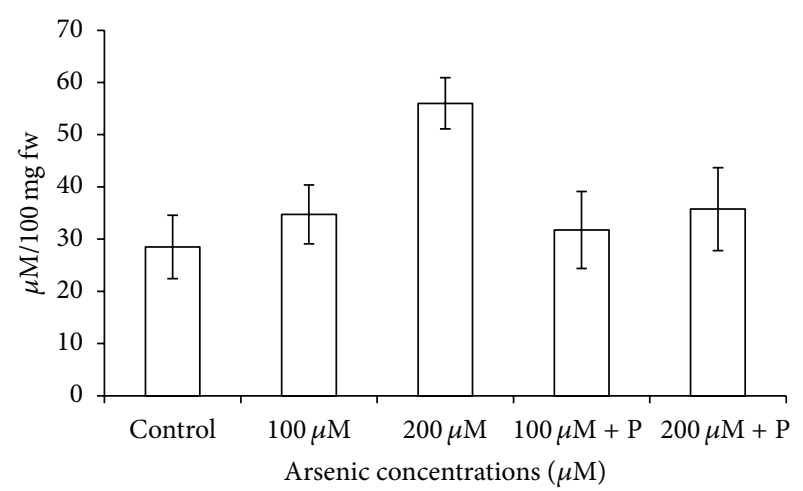

FIGURE 8: Effect of arsenate applied either singly or in combination with phosphate on the proline levels of black gram. Error bars are the $\pm \mathrm{SE}$ of three replicates; $\mathrm{P}=40 \mathrm{ppm} \mathrm{K} \mathrm{HPO}_{4}$.

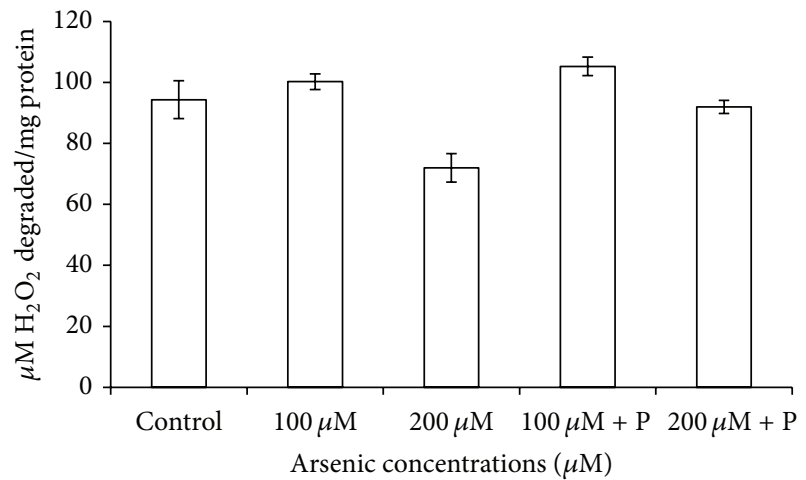

FIGURE 9: Effect of arsenate applied either singly or in combination with phosphate on the catalase activity of black gram. Error bars are the \pm SE of three replicates; $\mathrm{P}=40 \mathrm{ppm} \mathrm{K}_{2} \mathrm{HPO}_{4}$.

findings are similar to results reported for rice $[42,43]$ and wheat $[42,44]$.

The significant decrease of pigment contents in arsenictreated plants is a sign of absence of adaptive adjustments of pigment synthesis to high arsenic levels. In previous works too, increased arsenic levels resulted in change of the chloroplast shape with concaving membrane bending and partial destruction together with the changes in the accumulation and flow of assimilates that leads to the decrease of chlorophyll contents in rice leaf [45].

Increased lipid peroxidation in response to arsenic toxicity demonstrates increased generation of reactive oxygen species (ROS) in respect of oxidative stress. This is in accordance with previous reports that arsenic caused severe lipid peroxidation in mung bean [46], bean [47], and Pteris spp. $[48,49]$. An enhancement in MDA levels denotes occurrence of membrane damage resulting from peroxidation of polyunsaturated fatty acids, which causes generation of ROS and ensuing oxidative stress [50]. Arsenic induced membrane damage was also apparent from an increased electrolyte leakage (EL) from the leaves. ELP is an indicator of membrane damage and primarily occurs due to peroxidation of membrane that results from an oxidative burst [51]. Proline 


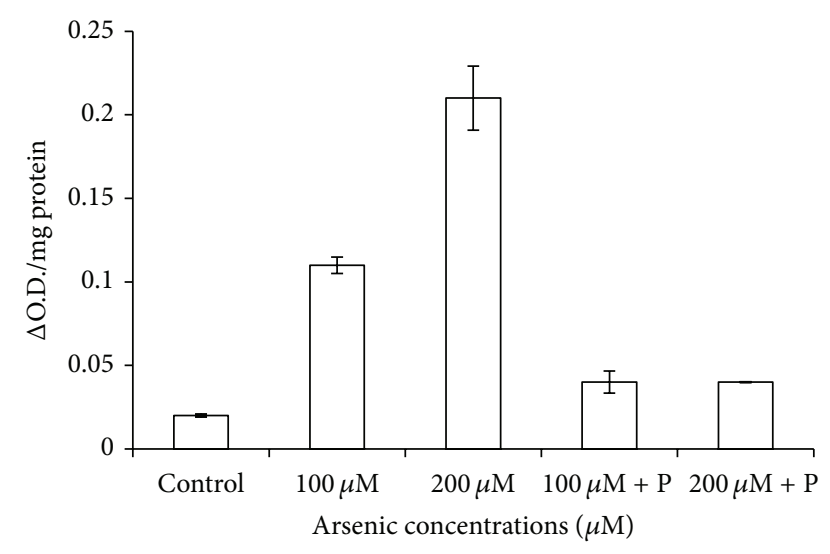

FIGURE 10: Effect of arsenate applied either singly or in combination with phosphate on the peroxidase activity of black gram. Error bars are the \pm SE of three replicates; $\mathrm{P}=40 \mathrm{ppm} \mathrm{K}_{2} \mathrm{HPO}_{4}$.

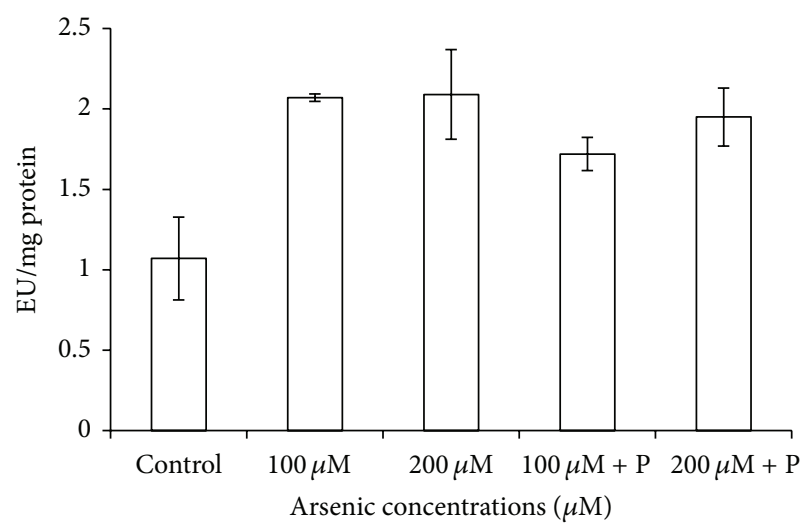

FIGURE 11: Effect of arsenate applied either singly or in combination with phosphate on the activity of superoxide dismutase in black gram. Error bars are the \pm SE of three replicates; $\mathrm{P}=40 \mathrm{ppm}$ $\mathrm{K}_{2} \mathrm{HPO}_{4}$.

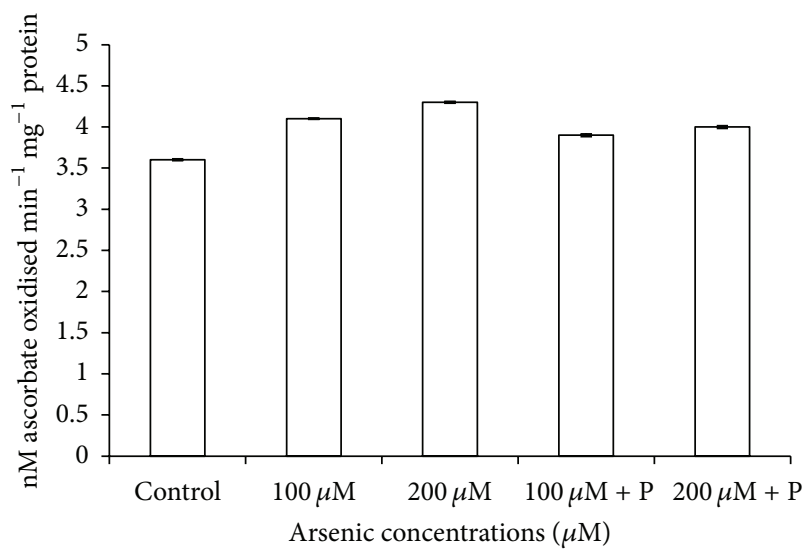

FIGURE 12: Effect of arsenate applied either singly or in combination with phosphate on the activity of ascorbate peroxidase in black gram. Error bars are the $\pm \mathrm{SE}$ of three replicates; $\mathrm{P}=40 \mathrm{ppm} \mathrm{K}_{2} \mathrm{HPO}_{4}$. acts as a cytoplasmic osmoticum and also protects the protein against denaturation [52]. Proline content, here, acting as stress marker for oxidative damage increased on application of arsenic whereas application of phosphate together with arsenic induced significant reduction of proline content.

It is well known that heavy metal toxicity of plants results into complex biochemical responses and many defensive mechanisms meant to detoxify ROS that readily occur in plants due to metal contamination [53, 54]. APX, CAT, SOD, $\mathrm{POX}$ are regarded as key enzymes within the antioxidative defense mechanism, which directly determines the cellular concentration of oxygen radicals, and $\mathrm{H}_{2} \mathrm{O}_{2}$. SOD is considered as the major superoxide $\left(\mathrm{O}_{2}{ }^{--}\right)$scavenger and also provides first line of defense against cellular injury due to environmental stress [55]. The highly reactive $\mathrm{O}_{2}{ }^{-}$is converted to $\mathrm{H}_{2} \mathrm{O}_{2}$ by SOD [56]. CAT is a heme containing tetrameric protein and one of the well-known $\mathrm{H}_{2} \mathrm{O}_{2}$ splitting enzymes [56]. Excess $\mathrm{H}_{2} \mathrm{O}_{2}$ generated due to $\mathrm{SOD}$ activity is detoxified by CAT. However, here, a significant decline in CAT activity at higher arsenic dose suggests that this enzyme is not involved in protection of black gram plants against arsenic toxicity. On the other hand, increased activity of POX and SOD enzymes on arsenic application suggests their protective role in arsenic toxicity. Results show an increase in the activity of APX in response to arsenic stress. APX utilizes the reducing power of ascorbic acid to remove potentially harmful $\mathrm{H}_{2} \mathrm{O}_{2}$ [48].

Arsenate acts as a $\mathrm{Pi}$ analogue and is transported across the plasma membrane via a Pi cotransport systems [26]. Once it is inside the cytoplasm, arsenate competes with $\mathrm{Pi}$, for example, replacing Pi in ATP to form unstable ADP-As. This leads to the disruption of energy flows in cells [42]. Also, in arsenate resistant plants with high $\mathrm{P}$ status a reduced As sensitivity has been noticed, which is not due to a difference in arsenate influx, but is probably a result of higher cytoplasmic Pi status, which decreases arsenate toxicity within the cell [53]. The effects due to P nutrition on metabolism of arsenate could be the following: (1) high plant P status that leads to a down regulation of the arsenate/Pi plasma lemma transporters; (2) high cellular Pi levels results in greater competition with arsenate for biochemical processes where arsenate substitutes for $\mathrm{Pi}$ [57]. Here also, all the parameters showed positive alterations in the presence of phosphate leading to better growth and metabolism in black gram. Arsenate tolerance could be enhanced by increasing Pi uptake [42]. Also, $\mathrm{P}$ nutrition could be involved in the reduction of reactive oxygen species and non protein thiols production, formed during exposure to As that cause tissue damage and lipid peroxidation [41]. P fertilization may reduce the impact of arsenic toxicity without increase in arsenic concentrations in above ground parts of plants [42].

\section{Conclusion}

The detrimental effect of toxic arsenic in black gram was clearly evident in the form of retarded growth and reduced biomass. This was further supported by elevated activity of oxidative stress markers and anti oxidative enzymes. This clearly shows that black gram is quite sensitive towards arsenic toxicity. However, phosphate application ameliorated 
to a large extent, the damaging effects caused by arsenic toxicity. This has practical importance in agricultural systems, as can reduce yield losses and also improve quality of crops.

\section{Acknowledgment}

Authors are grateful to Department of Botany, University of Lucknow, Lucknow, for providing the necessary facilities to carry out the experimental work.

\section{References}

[1] B. Rathinasabapathi, S. Wu, S. Sundaram, J. Rivoal, M. Srivastava, and L. Q. Ma, "Arsenic resistance in Pteris vittata L.: identification of a cytosolic triosephosphate isomerase based on cDNA expression cloning in Escherichia coli," Plant Molecular Biology, vol. 62, no. 6, pp. 845-857, 2006.

[2] A. H. Smith, C. Hopenhayn-Rich, M. N. Bates et al., "Cancer risks from arsenic in drinking water," Environmental Health Perspectives, vol. 97, pp. 259-267, 1992.

[3] E. Smith, R. Naidu, and A. M. Alston, "Arsenic in the soil environment: a review," Advances in Agronomy, vol. 64, no. C, pp. 149-195, 1998.

[4] J.-S. Lee, S.-W. Lee, H.-T. Chon, and K.-W. Kim, "Evaluation of human exposure to arsenic due to rice ingestion in the vicinity of abandoned Myungbong Au-Ag mine site, Korea," Journal of Geochemical Exploration, vol. 96, no. 2-3, pp. 231-235, 2008.

[5] A. Heikens, G. M. Panaullah, and A. A. Meharg, "Arsenic behaviour from groundwater and soil to crops: impacts on agriculture and food safety," Reviews of Environmental Contamination and Toxicology, vol. 189, pp. 43-87, 2007.

[6] S. Srivastava and Y. K. Sharma, "Arsenic occurrence and accumulation in soil and water of eastern districts of Uttar Pradesh, India," Environmental Monitoring and Assessment, vol. 185, no. 6, pp. 4995-5002, 2013.

[7] P. O’Neill, “Arsenic," in Heavy Metals in Soils, B. J. Alloway, Ed., pp. 105-121, 1995.

[8] O. P. Dhankher, "Arsenic metabolism in plants: an inside story," New Phytologist, vol. 168, no. 3, pp. 503-505, 2005.

[9] B. K. Mandal, Y. Ogra, and K. T. Suzuki, "Identification of dimethylarsinous and monomethylarsonous acids in human urine of the arsenic-affected areas in West Bengal, India," Chemical Research in Toxicology, vol. 14, no. 4, pp. 371-378, 2001.

[10] A. Mukherjee, M. K. Sengupta, M. A. Hossain et al., "Arsenic contamination in groundwater: a global perspective with emphasis on the Asian scenario," Journal of Health, Population and Nutrition, vol. 24, no. 2, pp. 142-163, 2006.

[11] S. Norra, Z. A. Berner, P. Agarwala, F. Wagner, D. Chandrasekharam, and D. Stüben, "Impact of irrigation with As rich groundwater on soil and crops: a geochemical case study in West Bengal Delta Plain, India," Applied Geochemistry, vol. 20, no. 10, pp. 1890-1906, 2005.

[12] S. M. I. Huq, R. Correll, and R. Naidu, "Arsenic accumulation in food sources in Bangladesh: variability with soil type," in Managing Arsenic in the Environment: From Soil To Human Health, R. Naidu, E. Smith, G. Owens, P. Bhattacharya, and P. Nadebaum, Eds., pp. 283-293, CSIRO Publishing, Melbourne, Australia, 2006.

[13] J. A. Davis, J. A. Coston, D. B. Kent, and C. C. Fuller, "Application of the surface complexation concept to complex mineral assemblages," Environmental Science and Technology, vol. 32, no. 19 , pp. $2820-2828,1998$.
[14] A. A. Meharg and M. Rahman, "Arsenic contamination of Bangladesh paddy field soils: implications for rice contribution to arsenic consumption," Environmental Science and Technology, vol. 37, no. 2, pp. 229-234, 2003.

[15] T. Roychowdhury, H. Tokunaga, T. Uchino, and M. Ando, "Effect of arsenic-contaminated irrigation water on agricultural land soil and plants in West Bengal, India," Chemosphere, vol. 58, no. 6, pp. 799-810, 2005.

[16] B. M. Dahal, M. Fuerhacker, A. Mentler, K. B. Karki, R. R. Shrestha, and W. E. H. Blum, "Arsenic contamination of soils and agricultural plants through irrigation water in Nepal," Environmental Pollution, vol. 155, no. 1, pp. 157-163, 2008.

[17] T. Roychowdhury, T. Uchino, H. Tokunaga, and M. Ando, "Survey of arsenic in food composites from an arsenic-affected area of West Bengal, India," Food and Chemical Toxicology, vol. 40, no. 11, pp. 1611-1621, 2002.

[18] A. A. Meharg, "Arsenic in rice: understanding a new disaster for South-East Asia," Trends in Plant Science, vol. 9, no. 9, pp. 415-417, 2004.

[19] A. C. Barrachina, F. B. Carbonell, and J. M. Beneyto, "Arsenic uptake, distribution, and accumulation in tomato plants: effect of arsenite on plant growth and yield," Journal of Plant Nutrition, vol. 18, no. 6, pp. 1237-1250, 1995.

[20] Q. Q. Jiang and B. R. Singh, "Effect of different forms and sources of arsenic crop yield and arsenic concentration," Water, Air, and Soil Pollution, vol. 74, no. 3-4, pp. 321-343, 1994.

[21] M. Tsutsumi, "Intensification of arsenic toxicity to paddy rice by hydrogen sulfide and ferrous iron. I. Induction of bronzing and iron accumulation in rice by arsenic," Soil Science and Plant Nutrition, vol. 26, no. 4, pp. 561-569, 1980.

[22] R. Frans, D. Horton, and L. Burdette, "Influence of MSMA on straighthead. Arsenic uptake and growth response in rice (Oryza sativa)," Arkansas Agricultural Experiment Station Report Series, vol. 30, pp. 1-12, 1988.

[23] A. R. Marin, P. H. Masscheleyn, and W. H. Patrick Jr., "The influence of chemical form and concentration of arsenic on rice growth and tissue arsenic concentration," Plant and Soil, vol. 139, no. 2, pp. 175-183, 1992.

[24] T. T. Tianjia Tang and D. M. Miller, "Growth and tissue composition of rice grown in soil treated with inorganic copper, nickel, and arsenic," Communications in Soil Science \& Plant Analysis, vol. 22, no. 19-20, pp. 2037-2045, 1991.

[25] K. Knauer, R. Behra, and H. Hemond, "Toxicity of inorganic and methylated arsenic to algal communities from lakes along an arsenic contamination gradient," Aquatic Toxicology, vol. 46, no. 3-4, pp. 221-230, 1999.

[26] C. I. Ullrich-eberius, A. Sanz, and A. J. Novacky, "Evaluation of arsenate- and vanadate-associated changes of electrical membrane potential and phosphate transport in Lemna gibba G1," Journal of Experimental Botany, vol. 40, no. 1, pp. 119-128, 1989.

[27] A. A. Meharg and J. Hartley-Whitaker, "Arsenic uptake and metabolism in arsenic resistant and nonresistant plant species," New Phytologist, vol. 154, no. 1, pp. 29-43, 2002.

[28] B. Göhl, Les Aliments Du Bétail Sous Les Tropiques, FAO, Division de Production et Santé Animale, Roma, Italy, 1982.

[29] D. I. Arnon, "Copper enzymes in isolated chloroplast, polyphenol-oxidase in Beta vulgaris," Plant Physiology, vol. 24, pp. 1-15, 1949.

[30] A. C. Duxbury and C. S. Yentsch, "Plankton pigment monographs," Journal of Marine Research, vol. 15, pp. 91-101, 1956. 
[31] R. L. Heath and L. Packer, "Photoperoxidation in isolated chloroplasts. I. Kinetics and stoichiometry of fatty acid peroxidation," Archives of Biochemistry and Biophysics, vol. 125, no. 1, pp. 189-198, 1968.

[32] L. S. Bates, R. P. Waldren, and I. D. Teare, "Rapid determination of free proline for water-stress studies," Plant and Soil, vol. 39, no. 1, pp. 205-207, 1973.

[33] C. Y. Sullivan and W. M. Ross, "Selecting for drought and heat resistance in grain sorghum," in Stress Physiology in Crop Plants, H. Mussell and R. Staples, Eds., John Wiley \& Sons, New York, NY, USA, 1979.

[34] H. Euler, W. Voa, and K. Josephson, “Uberkatalase I," Liebigs Annalen, vol. 452, pp. 158-181, 1927.

[35] H. Luck, "Catalase," in Method For Enzymatic Analysis, H. U. Bergmeyer, Ed., vol. 3, pp. 885-888, Academic Press, New York, NY, USA, 1965.

[36] C. Beauchamp and I. Fridovich, "Superoxide dismutase: improved assays and an assay applicable to acrylamide gels," Analytical Biochemistry, vol. 44, no. 1, pp. 276-287, 1971.

[37] Y. Nakano and K. Asada, "Hydrogen peroxide is scavenged by ascorbate-specific peroxidase in spinach chloroplasts," Plant and Cell Physiology, vol. 22, no. 5, pp. 867-880, 1981.

[38] O. H. Lowry, N. J. Rosebrough, A. L. Farr, and R. J. Randall, "Protein measurement with the Folin phenol reagent," The Journal of Biological Chemistry, vol. 193, no. 1, pp. 265-275, 1951.

[39] L. A. Kapustka, J. Lipton, H. Galbraith, D. Cacela, and K. LeJeune, "Metal and arsenic impacts to soils, vegetation communities and wildlife habitat in Southwest Montana uplands contaminated by smelter emissions: II. Laboratory phytotoxicity studies," Environmental Toxicology and Chemistry, vol. 14, no. 11, pp. 1905-1912, 1995.

[40] K. van den Broeck, C. Vandecasteele, and J. M. C. Geuns, "Speciation by liquid chromatography-inductively coupled plasmamass spectrometry of arsenic in mung bean seedlings used as a bio-indicator for the arsenic contamination," Analytica Chimica Acta, vol. 361, no. 1-2, pp. 101-111, 1998.

[41] J. Hartley-Whitaker, G. Ainsworth, and A. A. Meharg, "Copperand arsenate-induced oxidative stress in Holcus lanatus L. clones with differential sensitivity," Plant, Cell and Environment, vol. 24, no. 7, pp. 713-722, 2001.

[42] M. Pigna, V. Cozzolino, A. Violante, and A. A. Meharg, "Influence of phosphate on the arsenic uptake by wheat (Triticum durum L.) irrigated with arsenic solutions at three different concentrations," Water, Air, and Soil Pollution, vol. 197, no. 1-4, pp. 371-380, 2009.

[43] J. Abedin, M. S. Cresser, A. A. Meharg, J. Feldmann, and J. Cotter-Howells, "Arsenic accumulation and metabolism in rice (Oryza sativa L.)," Environmental Science and Technology, vol. 36, no. 5, pp. 962-968, 2002.

[44] Y. Liu, Y. G. Zhu, B. D. Chen, P. Christie, and X. L. Li, "Influence of the arbuscular mycorrhizal fungus Glomus mosseae on uptake of arsenate by the As hyperaccumulator fern Pteris vittata L," Mycorrhiza, vol. 15, no. 3, pp. 187-192, 2005.

[45] E. Miteva and M. Merakchiyska, "Response of chloroplasts and photosynthetic mechanism of bean plants to excess arsenic in soil," Bulgarian Journal of Agricultural Science, vol. 8, pp. 151156, 2002.

[46] H. P. Singh, D. R. Batish, R. K. Kohli, and K. Arora, "Arsenicinduced root growth inhibition in mung bean (Phaseolus aureus Roxb.) is due to oxidative stress resulting from enhanced lipid peroxidation," Plant Growth Regulation, vol. 53, no. 1, pp. 65-73, 2007.
[47] N. Stoeva, M. Berova, and Z. Zlatev, "Effect of arsenic on some physiological parameters in bean plants," Biologia Plantarum, vol. 49, no. 2, pp. 293-296, 2005.

[48] M. Srivastava, L. Q. Ma, N. Singh, and S. Singh, "Antioxidant responses of hyper-accumulator and sensitive fern species to arsenic," Journal of Experimental Botany, vol. 56, no. 415, pp. 1335-1342, 2005.

[49] N. Singh, L. Q. Ma, M. Srivastava, and B. Rathinasabapathi, "Metabolic adaptations to arsenic-induced oxidative stress in Pteris vittata L and $v$ L," Plant Science, vol. 170, no. 2, pp. 274282, 2006.

[50] J.-L. Montillet, S. Chamnongpol, C. Rustérucci et al., "Fatty acid hydroperoxides and $\mathrm{H}_{2} \mathrm{O}_{2}$ in the execution of hypersensitive cell death in tobacco leaves," Plant Physiology, vol. 138, no. 3, pp. 1516-1526, 2005.

[51] M. Bajji, J.-M. Kinet, and S. Lutts, "The use of the electrolyte leakage method for assessing cell membrane stability as a water stress tolerance test in durum wheat," Plant Growth Regulation, vol. 36, no. 1, pp. 61-70, 2002.

[52] P. B. Kavi Kishor, S. Sangam, R. N. Amrutha et al., "Regulation of proline biosynthesis, degradation, uptake and transport in higher plants: its implications in plant growth and abiotic stress tolerance," Current Science, vol. 88, no. 3, pp. 424-438, 2005.

[53] A. A. Meharg, "Integrated tolerance mechanisms: constitutive and adaptive plant responses to elevated metal concentrations in the environment," Plant, Cell and Environment, vol. 17, no. 9, pp. 989-993, 1994.

[54] N. Stoeva and T. Bineva, "Oxidative changes and photosynthesis in oat plants grown in as-contaminated soil," Bulgarian Journal of Plant Physiology, vol. 29, pp. 87-95, 2003.

[55] P. L. Gratão, A. Polle, P. J. Lea, and R. A. Azevedo, "Making the life of heavy metal-stressed plants a little easier," Functional Plant Biology, vol. 32, no. 6, pp. 481-494, 2005.

[56] B. Choudhury, S. Chowdhury, and A. K. Biswas, "Regulation of growth and metabolism in rice (Oryza sativa L.) by arsenic and its possible reversal by phosphate," Journal of Plant Interactions, vol. 6, no. 1, pp. 15-24, 2011.

[57] A. A. Meharg, "Mechanisms of plant resistance to metal and metalloid ions and potential biotechnological applications," Plant and Soil, vol. 274, no. 1-2, pp. 163-174, 2005. 

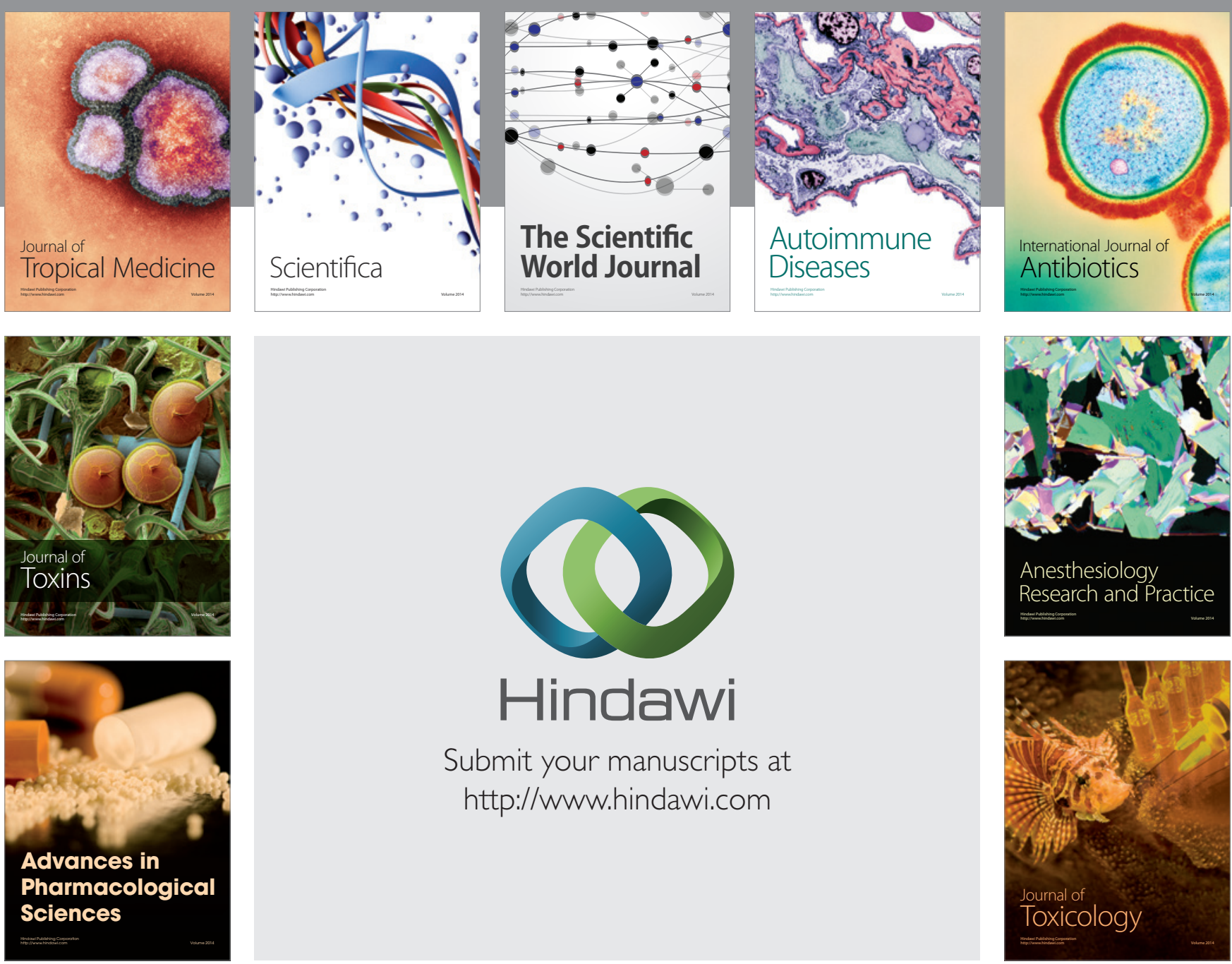

\section{Hindawi}

Submit your manuscripts at

http://www.hindawi.com
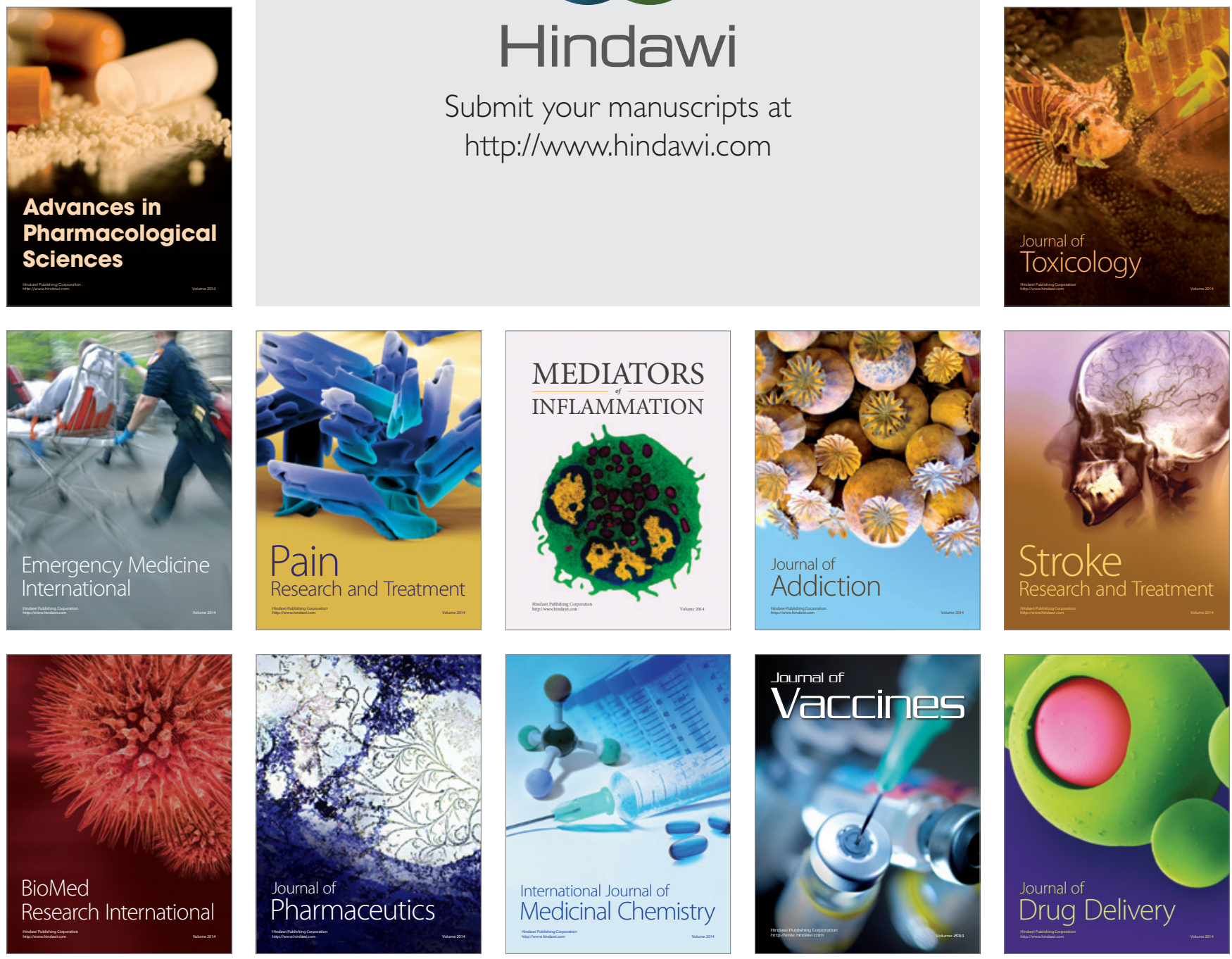